\title{
Article \\ Synthesis and Characterization of a New Norfloxacin/ Resorcinol Cocrystal with Enhanced Solubility and Dissolution Profile
}

\author{
Hanan Fael ${ }^{1}$, Rafael Barbas ${ }^{2}\left(\mathbb{D}\right.$, Rafel Prohens $^{2, *} \mathbb{D}$, Clara Ràfols ${ }^{1}\left(\mathbb{D}\right.$ and Elisabet Fuguet ${ }^{1, *}$ \\ 1 Departament d'Enginyeria Química i Química Analítica, Universitat de Barcelona, Martí i Franquès 1-11, \\ 08028 Barcelona, Spain; hananfael@hotmail.com (H.F.); crafols@ub.edu (C.R.) \\ 2 Unitat de Polimorfisme i Calorimetria, Centres Científics i Tecnologics, Universitat de Barcelona, \\ Baldiri Reixac 10, 08028 Barcelona, Spain; rafa@ccit.ub.edu \\ * Correspondence: rafel@ccit.ub.edu (R.P.); elifuguetj@ub.edu (E.F.)
}

Citation: Fael, H.; Barbas, R.; Prohens, R.; Ràfols, C.; Fuguet, E. Synthesis and Characterization of a New Norfloxacin/Resorcinol Cocrystal with Enhanced Solubility and Dissolution Profile. Pharmaceutics 2022, 14, 49. https://doi.org/ 10.3390/pharmaceutics14010049 Academic Editor: Andrea Erxleben

Received: 19 November 2021 Accepted: 23 December 2021 Published: 27 December 2021

Publisher's Note: MDPI stays neutral with regard to jurisdictional claims in published maps and institutional affiliations.

Copyright: (C) 2021 by the authors. Licensee MDPI, Basel, Switzerland. This article is an open access article distributed under the terms and conditions of the Creative Commons Attribution (CC BY) license (https:// creativecommons.org/licenses/by/ $4.0 /)$.

\begin{abstract}
A new cocrystal of Norfloxacin, a poorly soluble fluoroquinolone antibiotic, has been synthetized by a solvent-mediated transformation experiment in toluene, using resorcinol as a coformer. The new cocrystal exists in both anhydrous and monohydrate forms with the same (1:1) Norfloxacin/resorcinol stoichiometry. The solubility of Norfloxacin and the hydrated cocrystal were determined by the shake-flask method. While Norfloxacin has a solubility of $0.32 \pm 0.02 \mathrm{mg} / \mathrm{mL}$, the cocrystal has a solubility of $2.64 \pm 0.39 \mathrm{mg} / \mathrm{mL}$, approximately 10 -fold higher. The dissolution rate was tested at four biorelevant $\mathrm{pH}$ levels of the gastrointestinal tract: 2.0, 4.0, 5.5, and 7.4. In a first set of comparative tests, the dissolution rate of Norfloxacin and the cocrystal was determined separately at each $\mathrm{pH}$ value. Both solid forms showed the highest dissolution rate at $\mathrm{pH}$ 2.0, where Norfloxacin is totally protonated. Then, the dissolution rate decreases as $\mathrm{pH}$ increases. In a second set of experiments, the dissolution of the cocrystal was evaluated by a unique dissolution test, in which the pH dynamically changed from 2.0 to 7.4, stepping $30 \mathrm{~min}$ at each of the four biorelevant $\mathrm{pH}$ values. Results were quite different in this case, since dissolution at $\mathrm{pH} 2$ affects the behavior of Norfloxacin at the rest of the $\mathrm{pH}$ values.
\end{abstract}

Keywords: Norfloxacin; resorcinol; cocrystal; cocrystallization; dissolution rate; solubility

\section{Introduction}

The systemic effect of a drug starts with drug absorption, which in turn consists of a succession of rate processes: the release of the drug from the drug product, dissolution of the drug in an aqueous environment, and absorption across cell membranes into the systemic circulation. For drugs that have very poor aqueous solubility, the rate at which the drug dissolves (dissolution rate) is often the slowest step and therefore exerts a rate-limiting effect on drug bioavailability [1]. Nowadays, the low solubility is a major drawback related to drugs coming from synthesis, and this has a direct impact on their bioavailability [2]. To overcome this problem, diverse strategies have been developed. These include changing the crystal form (polymorphs, hydrates, etc.), formation of an amorphous phase, salt formation, formulation of solid dispersions with hydrophilic polymers [3], and inclusion of a complex formation with cyclodextrins [4]. Cocrystallization is an evolving technique that can dramatically modify the physical properties of drugs, such as stability, melting point, solubility, and dissolution rate, without altering the pharmacological effect of the drug candidate [5-8]. Therefore, increasing attention has been paid to cocrystallization as a tool to improve the pharmaceutical properties of drugs in the pharmaceutical industry and academic fields. A cocrystal can be defined as "a stoichiometric multi-component crystal form connected by non-covalent interactions where all the components present are solid under ambient conditions" $[6,9,10]$. Thus, a pharmaceutical cocrystal is composed 
of an active pharmaceutical ingredient (API) and a suitable organic and safe compound called the coformer [11]. There are several techniques to prepare cocrystals, such as solution crystallization (solvent evaporation/cooling) [12,13], mechanical grinding-in the absence of a solvent or in the presence of a minor amount of liquid [14] — and melt crystallization [15]. Norfloxacin (Figure 1) is a poorly soluble BCS class IV fluoroquinolone antibiotic [16]. It is a broad-spectrum antibiotic, effective against both Gram-positive and Gram-negative aerobic bacteria, and thus it is mainly used in the treatment of bacterial infections of the lower respiratory and urinary tracts [17]. Norfloxacin has relatively low oral bioavailability $(\sim 40 \%)$, limited by its poorly aqueous solubility $[18,19]$. The solid-state landscape of Norfloxacin was reviewed by some of us in 2010 [20], with only limited studies being reported on the cocrystallization of the drug: the sacharinate-sacharine dihydrate cocrystal [21], the isonicotinamide-chloroform cocrystal/solvate with a solubility increase of three-fold compared to the plain drug [20], and, most recently, the nicotinic acid cocrystal with solubility two-times greater than Norfloxacin [22].<smiles>CCn1cc(C(=O)O)c(=O)c2cc(F)c(N3CCNCC3)cc21</smiles>

Norfloxacin<smiles>Oc1cccc(O)c1</smiles>

\section{Resorcinol}

Figure 1. Molecular structures of Norfloxacin and resorcinol.

With the aim of improving the solubility and dissolution rate of Norfloxacin in the form of a pharmaceutical cocrystal, and considering these antecedents, resorcinol (Figure 1) was selected as the coformer in this work. It is a versatile compound with two strong hydrogen bond donor groups, with the potential to interact with both the carbonyl and amine hydrogen bond acceptor groups of Norfloxacin. Moreover, it shows important antioxidant properties, and its FEMA GRAS status [23], granted by the European Food Safety Authority [24], enables resorcinol to serve as an authorized flavoring substance without "safety concern at estimated levels of intake as flavouring substances". In fact, some of us have studied this coformer in other crystal engineering studies $[25,26]$, with the results demonstrating its remarkable ability to improve the stability of vitamin $\mathrm{D}_{3}$ via cocrystallization [27]. Resorcinol has also been previously utilized to prepare cocrystals with agomelatine [28], curcumin [29], and Ciprofloxacin, a fluoroquinolone antibiotic similar to Norfloxacin [30].

\section{Materials and Methods}

\subsection{Materials}

Norfloxacin (>98\%), resorcinol (>99\%), and toluene (>99.5\%) were purchased from Sigma Aldrich (Darmastadt, Germany). Norfloxacin was a mixture of polymorph A, polymorph C, and the sesquihydrate Form I (Ref Code PUZGAT). See Figure S1 for further details [31].

The following chemicals were used to prepare buffer solutions: ethylenediamine $(>98.8 \%)$ from J. T. Baker (Radnor, PA, USA), and trifluoroacetic acid (>99\%) and acetic acid ( $>99 \%$ ) from Merck (Darmastadt, Germany). To reach the desired $\mathrm{pH}$ value, $1 \mathrm{M}$ sodium hydroxide Titrisol ${ }^{\circledR}$ or $0.5 \mathrm{M}$ hydrochloric acid Titrisol ${ }^{\circledR}$, also from Merck, were added.

For the dissolution rate determination, the following reagents were used: dimethyl sulfoxide ( $>99.9 \%$, DMSO), potassium dihydrogen phosphate ( $>99.5 \%), 0.5 \mathrm{M}$ potassium hydroxide Titrisol ${ }^{\circledR}$, and $0.5 \mathrm{M}$ hydrochloric acid Titrisol ${ }^{\circledR}$, all from Merck. Potassium chloride (>99\%) was from Sigma. 
For HPLC quantification, acetonitrile (HPLC gradient-grade) from Fisher Scientific (Hampton, NH, USA) and a mixture of sodium dihydrogen phosphate monohydrate $(>99 \%)$ and disodium monohydrogen phosphate $(>99 \%)$ from Merck were used.

Water was purified by a Milli-Q plus system from Millipore (Bedford, MA, USA), with a resistivity of $18.2 \mathrm{M} \Omega \mathrm{cm}$.

\subsection{Synthesis of the Cocrystal}

Synthesis of the anhydrous Norfloxacin-resorcinol cocrystal was conducted by solventmediated transformation. In particular, Norfloxacin $(95.8 \mathrm{mg}, 0.300 \mathrm{mmol})$ and resorcinol $(39.6 \mathrm{mg}, 0.360 \mathrm{mmol})$ were stirred in toluene $(2.0 \mathrm{~mL})$ at room temperature $\left(25^{\circ} \mathrm{C}\right)$ overnight. The resulting suspension was filtered and dried under vacuum. Yield $=70 \%$. The Norfloxacin-resorcinol cocrystal monohydrate was isolated during the solubility/dissolution rate determination experiments.

\subsection{Differential Scanning Calorimetry (DSC)}

Differential scanning calorimetry measurements were carried out by means of a Mettler Toledo (Columbus, OH, US) DSC-822e calorimeter. Experimental conditions: aluminum crucibles of $40 \mu \mathrm{L}$, dry nitrogen with $50 \mathrm{~mL} / \mathrm{min}$ flow rate, heating from $30^{\circ} \mathrm{C}$ to $300{ }^{\circ} \mathrm{C}$ at a rate of $10^{\circ} \mathrm{C} / \mathrm{min}$. The calorimeter was calibrated with indium of $99.99 \%$ purity (m.p.: $156.6^{\circ} \mathrm{C} ; \Delta \mathrm{H}: 28.32 \mathrm{~J} / \mathrm{g}$ ).

\subsection{Thermogravimetric Analysis (TGA)}

Thermogravimetric measurements were performed on a Mettler Toledo TGA-851e thermobalance (Columbus, OH, US). Experimental conditions: alumina crucibles of $70 \mu \mathrm{L}$, dry nitrogen with $50 \mathrm{~mL} / \mathrm{min}$ flow rate, heating from $30{ }^{\circ} \mathrm{C}$ to $300{ }^{\circ} \mathrm{C}$ at a rate of $10^{\circ} \mathrm{C} / \mathrm{min}$. A blank curve was previously performed using the same methodology and it was subtracted.

\subsection{Nuclear Magnetic Resonance (NMR)}

Proton nuclear magnetic resonance $\left({ }^{1} \mathrm{H}-\mathrm{NMR}\right)$ spectra were measured on a Varian Mercury 400 (400 MHz) (Santa Clara, CA, US) spectrometer. Chemical shifts for proton are reported in parts per million (ppm) downfield from tetramethylsilane (TMS) and referenced to the residual proton signal in the NMR solvent $\left(\mathrm{dmso}-d_{6}: \delta 2.50\right)$. Experimental conditions, delay: 1 s; pulse: $45^{\circ}$; scans: 16 or 32 .

\subsection{X-ray Crystallographic Analysis}

X-ray powder diffraction (XRPD) patterns of new cocrystals of Norfloxacin were measured on a PANalytical (Malvern, UK) X'Pert PRO MPD (transmission configuration with $\mathrm{Cu} \mathrm{K} \alpha 1+2$ radiation, $\lambda=1.5406 \AA$ ) with a focalizing elliptic mirror and a PIXcel detector, and a maximum active detector length of $3.347^{\circ}$. The transmission geometry configuration included a convergent beam with a focalizing mirror, a flat sample sandwiched between low absorbing films measuring from 1 to $40^{\circ}$ in $2 \theta$, a step size of $0.026^{\circ}$, and a measuring time of $30 \mathrm{~min}$ at $298 \mathrm{~K}$.

\subsection{Solubility}

Solubility measurements were performed following the consensus recommendations for the shake-flask method described elsewhere [32]. A universal buffer composed of $75 \mathrm{mM}$ trifluoroacetic acid, $25 \mathrm{mM}$ acetic acid, and $25 \mathrm{mM}$ ethylenediamine, adjusted with $1 \mathrm{M}$ sodium hydroxide up to $\mathrm{pH} 7.5$, was used (ionic strength, $\mathrm{I}=0.1 \mathrm{M}$ ). Samples were prepared by adding a weighted amount of solid (enough to obtain saturated solutions) to $2 \mathrm{~mL}$ of the buffered solution. After this, solutions were shaken at a controlled temperature $\left(25.0 \pm 0.2{ }^{\circ} \mathrm{C}\right)$ for $24 \mathrm{~h}$, but, after $4 \mathrm{~h}$ of agitation, the $\mathrm{pH}$ was checked and, if necessary, readjusted to the initial value with small amounts of $1 \mathrm{M}$ hydrochloric acid or $1 \mathrm{M}$ sodium hydroxide solution. After the $24 \mathrm{~h}$ stirring, samples were left to stand for equilibration for 24 more hours [32-34]. The $\mathrm{pH}$ was measured and phases separated by centrifugation 
in a Rotanta 460RS centrifuge from Hettich Lab Technology (Tuttlingen, Germany), at a controlled temperature $\left(25^{\circ} \mathrm{C}\right)$ and $3500 \mathrm{rpm}$ for $30 \mathrm{~min}$.

The remaining solid was dried under vacuum for $30 \mathrm{~min}$ and stored at $4{ }^{\circ} \mathrm{C}$ until XRPD analysis. Solubility was obtained by quantifying the concentration of Norfloxacin and resorcinol in the supernatant by liquid chromatography. A Shimadzu (Kyoto, Japan) liquid chromatograph, equipped with two LC-10AD pumps and a SPD-10AV detector, was used. Temperature was controlled at $25.0 \pm 0.1{ }^{\circ} \mathrm{C}$ with a CTO-10AS column oven. The column was a Symmetry C18, with $5 \mu \mathrm{m}$ particle size and dimensions of $4.6 \times 150 \mathrm{~mm}$ from Waters (Milford, MA, USA). Mobile phase was composed of $20 \mathrm{mM}$ phosphate buffer at $\mathrm{pH} 7$ (A) and acetonitrile (B). Elution was in gradient mode (time (min), \%B: 0,$3 ; 1,3$; $5,25 ; 10,25 ; 12,3 ; 15,3)$. Flow rate was $1 \mathrm{~mL} / \mathrm{min}$, the injection volume was $10 \mu \mathrm{L}$, and the detection wavelengths were set at $254 \mathrm{~nm}$ for resorcinol and $267 \mathrm{~nm}$ for Norfloxacin. To quantify, six standard solutions were prepared in the linear range $\left(5-60 \mathrm{mgL}^{-1}\right.$ for both compounds). Standards were dissolved in an acetonitrile/water mixture at a proportion of $25 / 75(v / v)$. In a first attempt, saturated supernatants were injected directly, and, when necessary, they were appropriately diluted in water to ensure that they fit within the range of calibration. The calibration curve for resorcinol was $A=37217 C-3717\left(R^{2}=0.9988\right)$, and the calibration curve for Norfloxacin was $A=33554 C-29994\left(R^{2}=0.9991\right)$. None of the samples had concentrations below the most diluted standards $\left(5 \mathrm{mg} \mathrm{mL}^{-1}\right)$.

\subsection{Intrinsic Dissolution Rate (IDR)}

Molar extinction coefficients of Norfloxacin and resorcinol were determined by UVmetric titration using a GlpKaTM titrator (Sirius Analytical Instruments, Forest Row, UK). Briefly, a $10 \mathrm{mM}$ stock solution of each compound was prepared in DMSO. Then, $50 \mu \mathrm{L}$ of sample stock solution and $0.25 \mathrm{~mL}$ of $15 \mathrm{mM}$ potassium phosphate buffer were added to $10 \mathrm{~mL}$ of $0.15 \mathrm{M} \mathrm{KCl}$ solution. The $\mathrm{pH}$ was adjusted to 2 with $0.5 \mathrm{M} \mathrm{HCl}$ before starting the titration, and then the titration was done using $0.5 \mathrm{M} \mathrm{KOH}$ up to $\mathrm{pH} 12$. The UV absorption spectra (between 250 and $400 \mathrm{~nm}$ ) of the solution were recorded at each titrant addition by a fiber optic dip-probe. The collected data were refined through the Sirius T3 v. 2.0.0 software, and the $\mathrm{p} K_{a}$ values and Molar Extinction Coefficients obtained by Target Factor Analysis (Figure S11). The plot shows that the molar absorption of resorcinol was much lower than that of Norfloxacin in the whole studied wavelength range. In any case, quantification of Norfloxacin concentration was done from 300 to $400 \mathrm{~nm}$, a range in which resorcinol does not show absorbance.

Tablets of $3 \mathrm{~mm}$ diameter containing 7-9 mg of pure drug or Norfloxacin-resorcinol cocrystal were prepared using a manual hydraulic press (Applied Measurements Ltd., Reading, UK), applying a constant pressure of 0.1 ton for $2 \mathrm{~min}$. Dissolution tests were performed with a small-scale dissolution assay installed in the GlpKaTM titrator. The tablet was placed in a holder, and only one side of the tablet was exposed to the dissolution medium, with a total exposed surface area of $0.07 \mathrm{~cm}^{2}$. Then, $1.5 \mathrm{~mL}$ of $0.125 \mathrm{M}$ acetatephosphate buffer at $\mathrm{pH} 1.6$ was introduced into the vial without wetting the tablet surface. The instrument then automatically added a suitable volume of $0.15 \mathrm{M} \mathrm{KCl}$ solution and adjusted the $\mathrm{pH}$ to the required value. The final volume was $15 \mathrm{~mL}$. UV-visible absorption spectra were recorded every $30 \mathrm{~s}$ with a fiber-optic probe immersed in the solution.

To perform the 4-sector dissolution rate determinations, the same procedure was followed, but, after adjusting the initial $\mathrm{pH}$ to 2.0 and monitoring dissolution for $30 \mathrm{~min}$ at this $\mathrm{pH}$, the $\mathrm{pH}$ was automatically raised to the next value by addition of $\mathrm{KOH}$. Then, dissolution was monitored again for 30 more minutes. This stepping procedure was repeated until dissolution in the four sectors was covered.

The concentration of Norfloxacin in the solution at each time point was determined from the spectroscopic data by applying the Beer-Lambert law, using the previously determined molar extinction coefficients. Spectral regions where the signal was saturated 
(A > 1.5) were discarded. Dissolution rate was obtained through the fitting of the first-order Noyes-Whitney exponential equation to the data:

$$
[X]_{t}=S\left(1-e^{-k_{d}\left(t-t_{0}\right)}\right)
$$

In this equation, $[X]_{t}$ is the weight $(\mathrm{g})$ of compound in solution at a given time (min); $S$ is the extrapolated solubility $(\mathrm{g})$, and $k_{d}$ is the dissolution rate constant $\left(\mathrm{min}^{-1}\right) . t_{0}(\mathrm{~min})$ is a term allowing for a temporal offset. Dissolution rate is calculated through a refinement process in which $S, k_{d}$ and $t_{0}$ optimal values are obtained by minimizing the root mean square deviation between the modeled concentrations and the measured ones. Then, the dissolution rate $\left(\mathrm{g} \mathrm{min}^{-1}\right)$ is obtained by the product $k_{d} S$ [35].

\section{9. $p K_{a}$ Determination}

First, $5-6 \mathrm{mg}$ of compound were dissolved in $15 \mathrm{~mL}$ of a $0.15 \mathrm{M} \mathrm{KCl}$ aqueous solution. The sample was pre-alkalinized to $\mathrm{pH} 12$ with $0.5 \mathrm{M}$ standardized $\mathrm{KOH}$. Then, it was titrated with standardized $0.5 \mathrm{M} \mathrm{HCl}$. All titrations were carried out at $0.15 \mathrm{M}$ ionic strength and a temperature of $25^{\circ} \mathrm{C}$, under a nitrogen atmosphere. The $\mathrm{p} K_{a}$ values were calculated through the Sirius T3 v. 2.0.0 software. The Debye-Hückel equation was used to obtain the thermodynamic $\mathrm{p} K_{a}$ values.

\section{Results and Discussion}

\subsection{Characterization of the Cocrystals}

The Norfloxacin-resorcinol cocrystal was obtained in two different crystal forms, one anhydrous and one monohydrate with the same (1:1) API/coformer stoichiometry, based on NMR and TGA measurements and further characterized by means of XRPD and DSC. The XRPD diffractogram of the anhydrous Norfloxacin-resorcinol cocrystal was indexed with the following proposed triclinic cell: $\mathrm{a}=18.427(5) \AA, \mathrm{b}=14.593(3) \AA \mathrm{A}, \mathrm{c}=19.613(6) \AA$, $\alpha=44.30(2)^{\circ}, \beta=139.73(2)^{\circ}, \gamma=133.25(1)^{\circ}$ and $V=2265(1) \AA^{3}$ by means of Dicvol04 [36] (Figures of Merit: $\mathrm{M}=11, \mathrm{~F}=31$ ) with a number of impurities equal to zero. The cell volume is compatible with four molecules of Norfloxacin and four molecules of resorcinol, $\mathrm{Z}=4$ (Figure 2).

The powder diffractogram of the Norfloxacin-resorcinol cocrystal monohydrate was indexed with the following proposed monoclinic cell: $\mathrm{a}=18.336(2) \AA, \mathrm{b}=7.8407(7) \AA$, $c=15.577(4) \AA, \beta=109.580(9)^{\circ}$ and $V=2110.0(6) \AA^{3}$ by means of Dicvol04 (Figures of Merit: $\mathrm{M}=54, \mathrm{~F}=165)$ with a number of impurities equal to zero. The $P 2_{1} / n$ space group was determined based on the assessment of systematic absences and the cell volume is compatible with four molecules of Norfloxacin, four molecules of resorcinol and four molecules of water, $\mathrm{Z}=4$ (Figure 3).

On the other hand, the DSC analysis of the bulk anhydrous powder of the Norfloxacinresorcinol cocrystal showed an endothermic phenomenon at $198^{\circ} \mathrm{C}$ with an associated heat of $114.4 \mathrm{~J} / \mathrm{g}$ (Figure S2, Supplementary Materials). The TGA analysis did not show a weight loss before melting (Figure S3, Supplementary Materials). Its powder diffractogram was indexed and the cell volume is compatible with one molecule of Norfloxacin and one molecule of resorcinol in the asymmetric unit. On the other hand, the DSC analysis of the bulk monohydrate powder of the Norfloxacin-resorcinol cocrystal showed a first wide endothermic phenomenon starting at $62{ }^{\circ} \mathrm{C}$ with an associated heat of $124.3 \mathrm{~J} / \mathrm{g}$, a second endothermic phenomenon at $124^{\circ} \mathrm{C}$ with an associated heat of $3.7 \mathrm{~J} / \mathrm{g}$, followed by an exothermic phenomenon with an associated heat of $36.5 \mathrm{~J} / \mathrm{g}$ and, finally, a third endothermic phenomenon at $189{ }^{\circ} \mathrm{C}$ with an associated heat of $128.6 \mathrm{~J} / \mathrm{g}$, (Figure S6, Supplementary Materials). Moreover, and with the aim of characterizing the melting point of the monohydrate cocrystal, a DSC experiment was run at a $10^{\circ} \mathrm{C} / \mathrm{min}$ heating rate without a hole in the crucible. The thermogram showed a first endothermic phenomenon at $147^{\circ} \mathrm{C}$ with an associated heat of $66.0 \mathrm{~J} / \mathrm{g}$ and a second endothermic phenomenon at $186^{\circ} \mathrm{C}$ with and associated heat of $141.7 \mathrm{~J} / \mathrm{g}$ (Figure S7, Supplementary Materials). The TGA 
analysis showed a weight loss of $3.8 \%$ detected from 30 to $138^{\circ} \mathrm{C}$, which can be attributed to one molecule of water per molecule of Norfloxacin and resorcinol (theoretical weight loss of 3.9\%) (Figure S8, Supplementary Materials). Its powder diffractogram was indexed and the cell volume is compatible with one molecule of Norfloxacin, one molecule of resorcinol and one molecule of water in the asymmetric unit. XRPD diffractograms of this multicomponent system compared to pure Norfloxacin and resorcinol are shown in Figure 4, and characteristic 2theta peaks of each form can be found in Table S1 of the Supplementary Materials. Finally, the ${ }^{1} \mathrm{H}-\mathrm{NMR}$ spectra of the obtained cocrystals were measured and the resonance peaks integrated to determine the API/conformer stoichiometric ratio in each cocrystal. Upon quantitative analysis of the ${ }^{1} \mathrm{H}-\mathrm{NMR}$ spectra, both Norfloxacin-resorcinol cocrystals were found to have a 1:1 molar ratio (see ESI for further characterization details).

WDICVOL04 solution (Automatic generated PCR file) Chi2: 32.7992

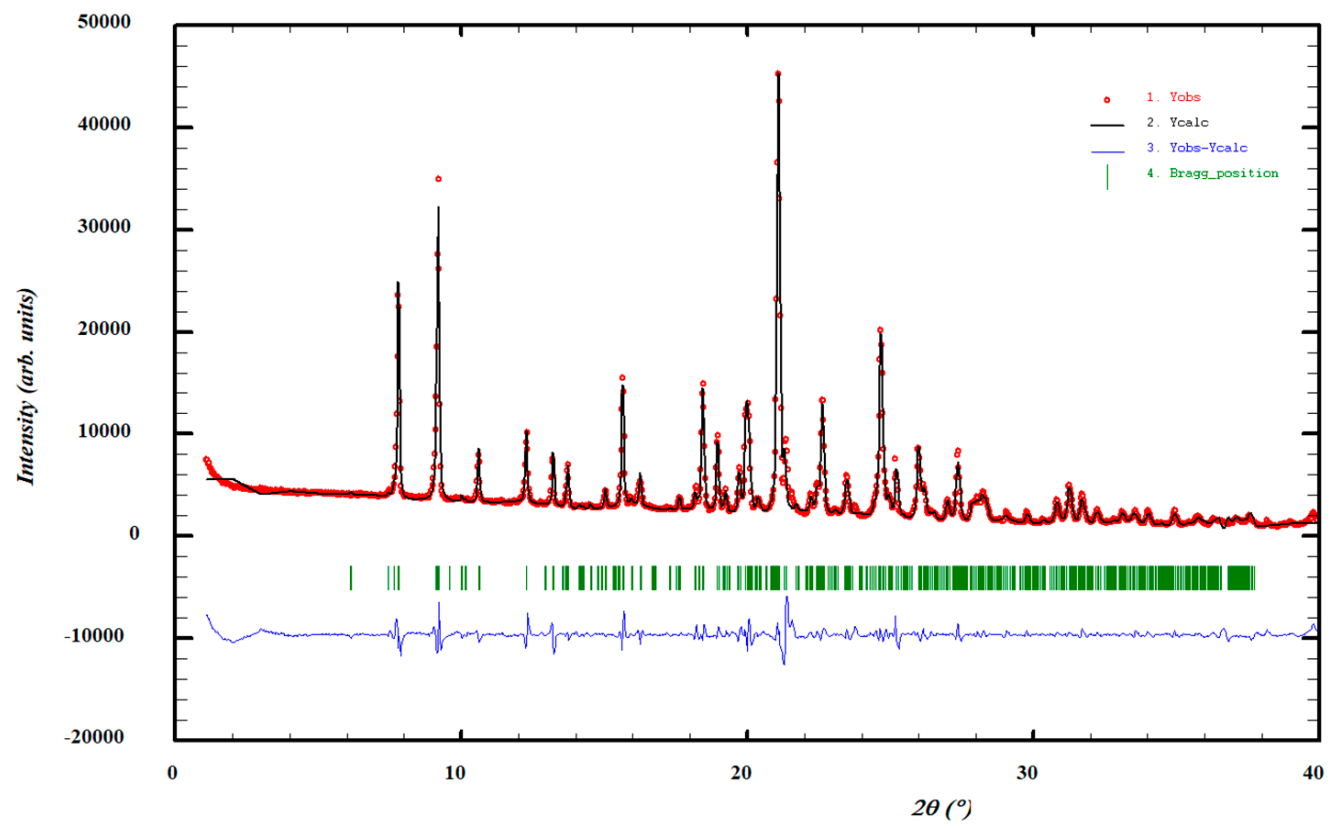

Figure 2. Pattern matching refinement of the Norfloxacin-resorcinol cocrystal. Agreement factors: $\mathrm{R}_{\mathrm{wp}}$ : 9.5\%; $\mathrm{R}_{\text {exp }}: 1.7 \%\left(\mathrm{Chi}^{2}=33\right)$. Experimental XRPD profile (red marks), calculated XRPD profile (black solid line) and the difference between them (blue, line). Tick marks correspond to peak positions ( 1 , in green).

\subsection{Solubility Study}

The solubility of Norfloxacin and the solubility product of the anhydrous cocrystal were measured by the shake-flask method [32-34]. Norfloxacin is a diprotic zwitterionic compound with $\mathrm{p} K_{a}$ values in water of $6.35 \pm 0.04$ and $8.80 \pm 0.04\left(25{ }^{\circ} \mathrm{C}\right.$ and 0 ionic strength, determined by potentiometry) [37]. Therefore, it will be in its ionic form at low (cation) and high (anion) $\mathrm{pH}$ values. However, as the two $\mathrm{p} K_{a}$ values are quite close, a $\mathrm{pH}$ region in which only the zwitterionic form is present in the solution does not exist. The maximum percentage of the zwitterionic form (around 90\%) will be obtained at a $\mathrm{pH}$ in between the two $\mathrm{pK} K_{a}$ s, i.e., 7.5 (see Figure $S 12$ in the supplementary materials). This is also the $\mathrm{pH}$ at which Norfloxacin is expected to show the lowest solubility. 
WDICVOL04 solution (Automatic generated PCR file) Chi2: 13.2153

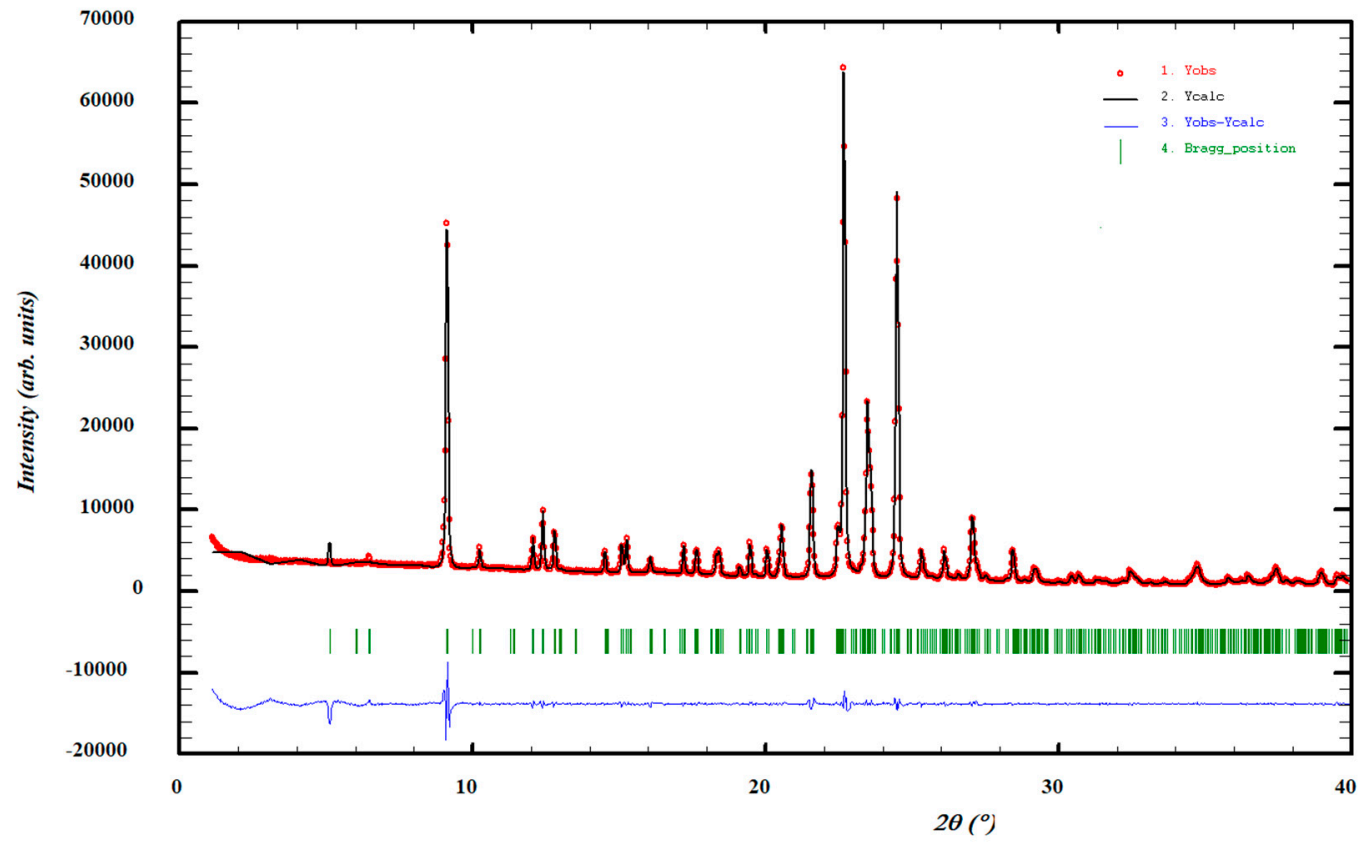

Figure 3. Pattern matching refinement of the Norfloxacin-resorcinol cocrystal monohydrate. Agreement factors: $\mathrm{R}_{\mathrm{wp}}: 6.5 \%$; $\mathrm{R}_{\mathrm{exp}}: 1.8 \%\left(\mathrm{Chi}^{2}=13\right.$ Experimental XRPD profile (red marks), calculated XRPD profile (black solid line) and the difference between them (blue, line). Tick marks correspond to peak positions ( 1 , in green).

\section{Counts}

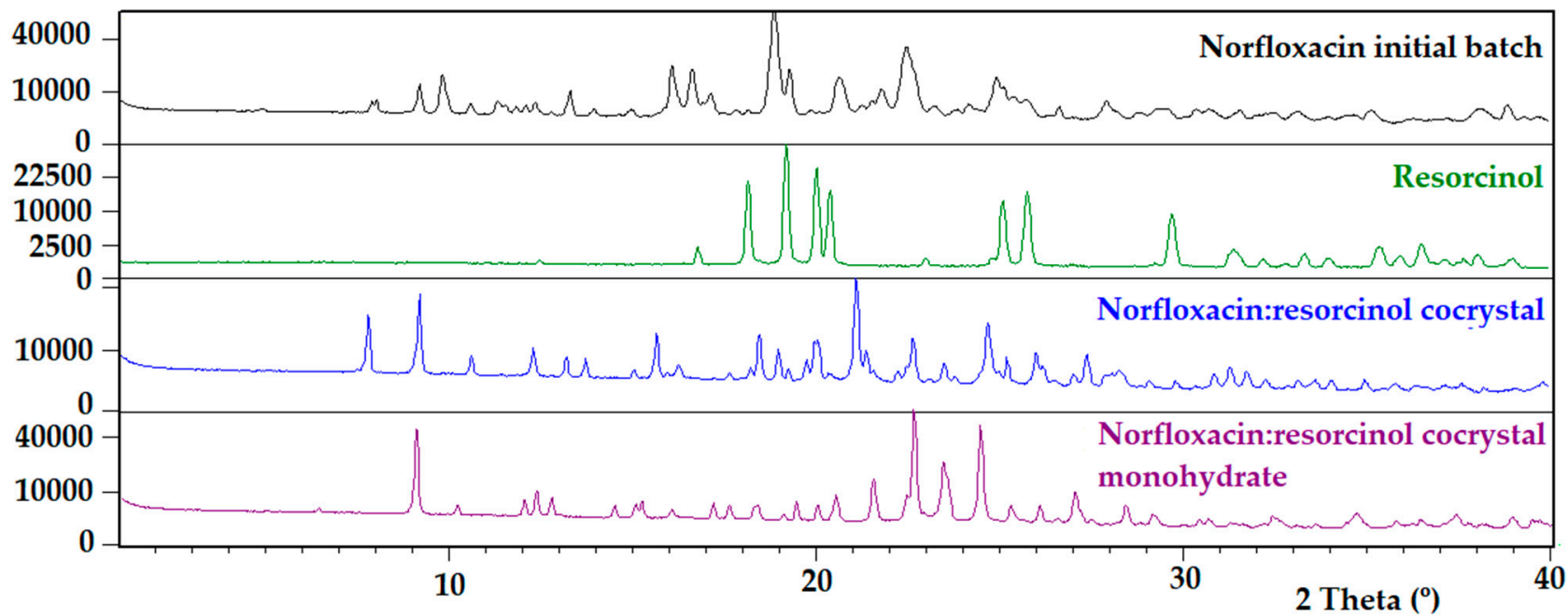

Figure 4. XRPD diffractograms of anhydrous and monohydrate forms of Norfloxacin-resorcinol cocrystal compared to Norfloxacin initial batch and resorcinol.

In the case of a zwitterionic compound such as Norfloxacin, a saturated solution can be defined by the following equilibria and the related constants:

$$
\begin{aligned}
\mathrm{H}_{2} \mathrm{X}^{+} \leftrightarrow \mathrm{HX}^{ \pm}+\mathrm{H}^{+} & K_{a 1}=\frac{\left[\mathrm{HX}^{ \pm}\right]\left[\mathrm{H}^{+}\right]}{\left[\mathrm{H}_{2} \mathrm{X}^{+}\right]} \\
\mathrm{HX}^{ \pm} \leftrightarrow \mathrm{X}^{-}+\mathrm{H}^{+} & K_{a 2}=\frac{\left[\mathrm{X}^{-}\right]\left[\mathrm{H}^{+}\right]}{\left[\mathrm{HX}^{ \pm}\right]}
\end{aligned}
$$




$$
\mathrm{HX}_{(\mathrm{s})}^{ \pm} \leftrightarrow \mathrm{HX}^{ \pm} \quad S_{0}=\left[\mathrm{HX}^{ \pm}\right]
$$

where $S_{0}$ is the solubility of the neutral species-in the present case, the zwitterionic one. The total concentration of Norfloxacin in the solution is the sum of the concentrations of all the species dissolved in the aqueous phase, given by the mass balance:

$$
C_{\mathrm{Nor}}=\left[\mathrm{H}_{2} \mathrm{X}^{+}\right]+\left[\mathrm{HX}^{ \pm}\right]+\left[\mathrm{X}^{-}\right]
$$

In a saturated solution, the total concentration is the solubility, $S$, so Equation (5) is converted to:

$$
S_{\mathrm{Nor}}=\left[\mathrm{H}_{2} \mathrm{X}^{+}\right]+\left[\mathrm{HX}^{ \pm}\right]+\left[\mathrm{X}^{-}\right]
$$

It is useful to convert the above equation into an expression containing only constants and $\left[\mathrm{H}^{+}\right]$as the only variable, by substituting the ionization and solubility Equations (2)-(4) into Equation (6). Then, Equation (7) is obtained:

$$
\log S_{\text {Nor }}=\log S_{0}+\log \left(10^{\mathrm{p} K_{1}-\mathrm{pH}}+10^{\mathrm{pH}-\mathrm{p} K_{2}}+1\right)
$$

The chromatographic quantification of the saturated solutions after the shake-flask process provides a solubility for Norfloxacin of $0.394 \pm 0.018 \mathrm{mg} / \mathrm{mL}(n=3$, final $\mathrm{pH} 7.25$ after the shake-flask process). From this solubility value and Equation (7), it is possible to calculate the intrinsic solubility for the zwitterionic form $\left(S_{0}\right)$, which is $0.319 \pm 0.019 \mathrm{mg} / \mathrm{mL}$. Note that, as the ionic strength in solubility determinations is $0.1 \mathrm{M}$, in this latter calculation, $\mathrm{p} K_{a}$ values have been converted to $\mathrm{p} K_{a}{ }^{\prime}$ values (acidity constant at the working ionic strength, where hydrogen ion is expressed as activity and the rest of the species as concentrations) [38]. This $S_{0}$ value is in agreement with literature values. Avdeef reported the average of $18 S_{0}$ determinations from different sources, in all cases performed by the shake-flask method, with $S_{0}$ values ranging from 0.29 to $0.61 \mathrm{mg} / \mathrm{mL}$ [39].

The solubility of the anhydrous Norfloxacin-resorcinol cocrystal was calculated in a similar way. Resorcinol is a very weak diprotic acid. The first ionization has a $\mathrm{p} K_{a}$ of $9.47 \pm 0.02\left(25^{\circ} \mathrm{C}\right.$ and 0 ionic strength, determined by potentiometry), and the second $\mathrm{p} K_{a}$ is even higher (11.60 \pm 0.04$)$ [37]. For the cocrystal, the solubility product can be defined as:

$$
\mathrm{HX}^{ \pm} \cdot \mathrm{HA}_{(s)} \leftrightarrow \mathrm{HX}^{ \pm}+\mathrm{HA} \quad K_{p s}=\left[\mathrm{HX}^{ \pm}\right][\mathrm{HA}]
$$

In this equilibrium, HA stands for resorcinol, which, at the working $\mathrm{pH}$ of the present study (7.5), can be treated as a monoprotic acid. Similar to the solubility equilibrium of a single compound, in a cocrystal, the solid cocrystal is in equilibrium with the two components in the solution. The acid-base equilibrium of resorcinol can be expressed as

$$
\mathrm{HA} \leftrightarrow \mathrm{A}^{-}+\mathrm{H}^{+} \quad K_{a}=\frac{\left[\mathrm{A}^{-}\right]\left[\mathrm{H}^{+}\right]}{[\mathrm{HA}]}
$$

Moreover, the total concentration of resorcinol in the solution is given by the mass balance through Equation (10):

$$
C_{\text {Res }}=[\mathrm{HA}]+\left[\mathrm{A}^{-}\right]
$$

Combination of Equations (9) and (10) allows the calculation of the species [HA] at any $\mathrm{pH}$ value, simply quantifying the total amount of resorcinol in the solution, $C_{\mathrm{Res}}$ (Equation (11)):

$$
[\mathrm{HA}]=\frac{C_{\mathrm{Res}}}{1+10^{\mathrm{pH}-\mathrm{pK}}}
$$


Similarly, combination of Equations (2) and (3) into Equation (5) provides the following expression, which allows the calculation of the concentration of $\left[\mathrm{HX}^{ \pm}\right]$at any $\mathrm{pH}$ value, simply quantifying the total concentration of Norfloxacin in the solution $\left(C_{\text {Nor }}\right)$ :

$$
\left[\mathrm{HX}^{ \pm}\right]=\frac{C_{\mathrm{Nor}}}{10^{\mathrm{pK}_{a 1}-\mathrm{pH}}+10^{\mathrm{pH}-\mathrm{pK}_{a 2}+1}}
$$

The substitution of Equations (11) and (12) into Equation (8) allows the calculation of the solubility product of the cocrystal, which has a value of $3.85 \times 10^{-5} \pm 1.20 \times 10^{-5}(n=4)$. Then, the solubility of the cocrystal is easily calculated:

$$
S=\sqrt{K_{p s}}
$$

The solubility of the Norfloxacin-resorcinol cocrystal is $2.64 \pm 0.39 \mathrm{mg} / \mathrm{mL}$, almost 10-fold higher than the solubility of the API alone.

XRPD analysis of the solid phase obtained after the shake-flask experiments stated that there was a transformation of both solid forms during the solubility tests. Commercial Norfloxacin (which was a mixture of polymorph A, polymorph C, and the sesquihydrate Form I (Ref Code PUZGAT)) was transformed during the process to a tetrahydrate (according to TGA analysis and XRPD comparison with known forms of Norfloxacin; see Figures S14-S16 of Supplementary Information), so, in fact, the solubility values provided in this section correspond to the tetrahydrate form. In the case of the cocrystal, the anhydrous form was converted into a new form, which was identified and characterized in Section 3.1 as a monohydrate. Therefore, it is not possible to obtain the solubility of the initial solid form in either of the two cases, since transformations occur during the course of the experiments in contact with aqueous solutions.

\subsection{Intrinsic Dissolution Rate Study}

The dissolution rates of Norfloxacin and the anhydrous Norfloxacin-resorcinol cocrystal were determined at four different $\mathrm{pH}$ values $(2.0,4.0,5.5$, and 7.4). These values were chosen because they can be encountered in different parts of the gastrointestinal tract (GIT), so they should be adequate to evaluate the behavior of the compounds after oral intake. Figure 5 shows the dissolution profiles obtained at each $\mathrm{pH}$, and Table 1 shows the dissolution percentage reached after $30 \mathrm{~min}$ of dissolution, together with the dissolution rate values obtained through the fitting of Equation (1) to the experimental data. Table 1 also shows the solid form identity results corresponding to the characterization of, on one hand, the initial solid forms and, on the other hand, the solid obtained after the dissolution experiments.

Figure 5A shows the dissolution profiles at $\mathrm{pH}$ 2. The initial slope of both curves is practically coincident, so Norfloxacin dissolves at the same rate independently of the solid form in which it exists. However, after $5 \mathrm{~min}$, the dissolution rate of the cocrystal tends to be slightly lower, as the average slope decreases. This difference can be related to the presence of resorcinol in the solution. However, it must be noted that the dissolution experiments of Norfloxacin at this $\mathrm{pH}$ are very reproducible, whereas the error bars indicate high variability in the dissolution of the cocrystal in the time range of 0-15 min (sometimes, it dissolves similarly to the API, and, sometimes, the process is slightly slower). The lower reproducibility is mainly attributed to the different physical properties of the two tablets, since the Norfloxacin and cocrystal powders are physically different. In any case, the percentage of dissolution is very high in both cases $(100 \%$ for Norfloxacin alone, $94 \%$ for the cocrystal). This is expected since, at such low $\mathrm{pH}$, the API is in its cationic form.

Particularly interesting are the dissolution profiles obtained at $\mathrm{pH} 4.0$ (Figure 5B). According to the Norfloxacin $\mathrm{p} K_{a}$ values, a similar profile as the one at $\mathrm{pH} 2.0$ would be expected (see Figure S12). However, the slope decreases markedly from $\mathrm{pH} 2.0$ to $\mathrm{pH}$ 4.0, especially in the API curve. Compared to $\mathrm{pH} 2$, the percentage of dissolved Norfloxacin after 30 min of dissolution is similar in the cocrystal tablet, whereas it falls to $71 \%$ in the API tablet. This behavior has been reported for some ionizable APIs-Ciprofloxacin, among 
others [30] - and can be explained by the change in $\mathrm{pH}$ at the tablet-solution interface $\left(\mathrm{pH}_{\mathrm{x}=0}\right.$ effect) [40]. When a large amount of API is dissolved, a saturated API solution is created only at the interface with the tablet surface. As a result, the $\mathrm{pH}$ at the interface is shifted according to the acid-base nature of the API, because the high concentration of API hinders the buffer's capacity to keep the $\mathrm{pH}$ constant.
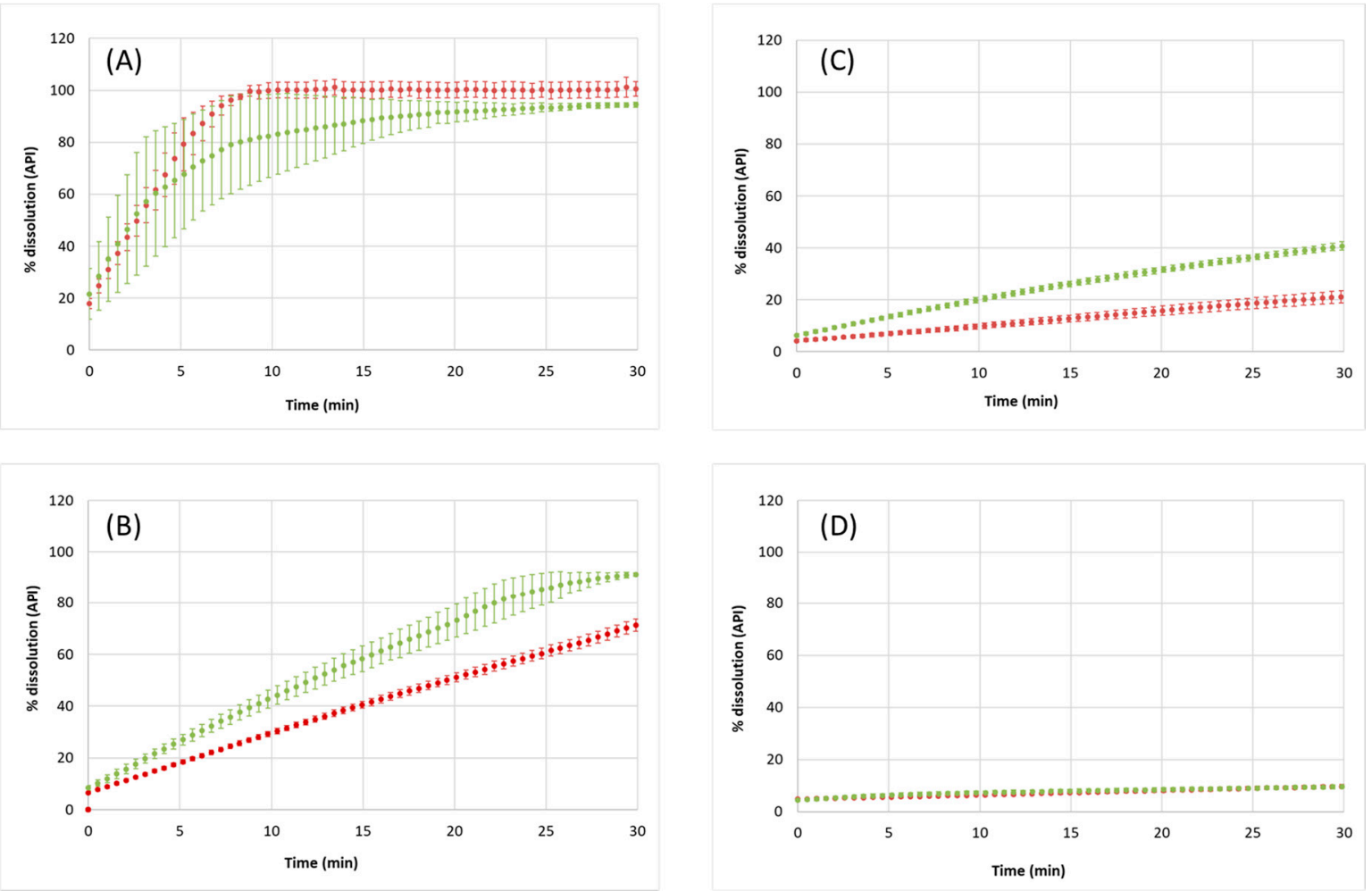

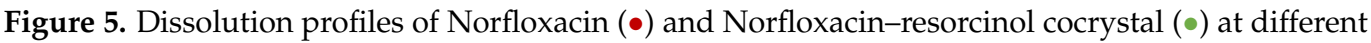
pH values: pH 2.0 (A); pH 4.0 (B); pH 5.5 (C), and pH 7.4 (D).

Table 1. Percentage of dissolution and dissolution rate $\left(\mu \mathrm{g} \mathrm{min}^{-1}\right)$ of Norfloxacin and Norfloxacinresorcinol cocrystal at different GIT $\mathrm{pH}$ values. Standard deviations are given in brackets.

\begin{tabular}{cccccc}
\hline Compound & $\begin{array}{c}\text { Starting } \\
\text { Solid Form }\end{array}$ & pH & $\begin{array}{c}\text { \% Dissolved } \\
\text { at } \mathbf{t}=\mathbf{3 0} \text { min }\end{array}$ & $\begin{array}{c}\text { Dissolution } \\
\text { Rate }\end{array}$ & $\begin{array}{c}\text { Final Solid } \\
\text { Form }\end{array}$ \\
\hline & & 2.0 & $101.2(6.3)$ & $4.16(0.73)$ & \\
Norfloxacin & Mixture of & 4.0 & $71.3(6.9)$ & $0.79(0.03)$ & Tetrahydrate \\
& polymorphs & 5.5 & $23.0(5.2)$ & $0.19(0.02)$ & \\
& & 7.4 & $9.4(1.0)$ & $0.06(0.01)$ & \\
Norfloxacin-resorcinol & \multirow{2}{*}{ Anhydrous } & 4.0 & $91.2(0.9)$ & $0.70(0.15)$ & Monohydrate \\
cocrystal & & 5.5 & $48.0(12.5)$ & $0.33(0.04)$ & \\
& & 7.4 & $9.6(1.0)$ & $0.19(0.10)$ & \\
\hline
\end{tabular}

To prove this, a set of vials with dissolution media at $\mathrm{pH} 4.0,5.5$, and 7.4 were prepared (identical amount as in the dissolution rate experiments). However, instead of adding a Norfloxacin tablet, the powder was directly weighted into the vials until saturated solutions of Norfloxacin were obtained. Then, the solutions were allowed to stand under agitation at $25{ }^{\circ} \mathrm{C}$ for $24 \mathrm{~h}$. After this, the $\mathrm{pH}$ of the solutions was measured again. The new $\mathrm{pH}$ values were $5.8,6.2$, and 7.4, respectively, i.e., there were positive $\mathrm{pH}$ increments of 1.8, 0.7, and 0 units, respectively. This additional test simulates what is happening at the interface, revealing a $\mathrm{pH}$ higher than the one of the bulk solution, and causing a decrease in the 
dissolution process. This effect is more evident for the API dissolution than for the cocrystal because the amount of API released in the cocrystal is lower compared to the pure API.

The same phenomenon is observed in the profiles at $\mathrm{pH}$ 5.5. At this $\mathrm{pH}$, there is part of Norfloxacin in the zwitterionic form already, so a decrease in dissolution rate is expected. Nevertheless, the $\mathrm{pH}_{\mathrm{x}=0}$ effect can be also noticed, although at a lower degree, and the cocrystal dissolves faster than the API. Notice that, at $\mathrm{pH} 4$ and $\mathrm{pH} 5.5$, there is no overlapping in the error bars, so dissolution is clearly different for the two solid forms. In the cocrystal, dissolution of $48 \%$ of the API is observed after $30 \mathrm{~min}$, whereas the percentage in solution achieved with API tablets is only $23 \%$.

Finally, the profiles at $\mathrm{pH} 7.4$ show the same behavior for the API and the cocrystal. Here, the amount of API in the solution decreases to $7 \%$. In fact, at this $\mathrm{pH}$, the solubility of Norfloxacin has the minimum value, which is, in some way, reflected in the dissolution curves. Moreover, this $\mathrm{pH}$ is not affected by the $\mathrm{pH}_{\mathrm{x}=0}$ phenomenon since this is the $\mathrm{pH}$ provided by an unbuffered Norfloxacin saturated solution, so, in this particular case, the cocrystal does not present any advantage over the API in the dissolution process.

This dissolution rate behavior is similar to that observed in a preliminary study conducted for a Ciprofloxacin-resorcinol cocrystal [30]. In fact, both APIs belong to the same family, and they have similar structures and $\mathrm{pK}_{a}$ values, so similar dissolution rate behavior was expected.

In order to determine whether the dissolution behavior of the cocrystal is the same in a dynamic process along the GIT pH levels, the dissolution test was repeated while monitoring the dissolution in a full sequence of $\mathrm{pH}$ values (starting from 2.0 up to 7.4), remaining for $30 \mathrm{~min}$ at each $\mathrm{pH}$ value. Figure 6 shows the results obtained.

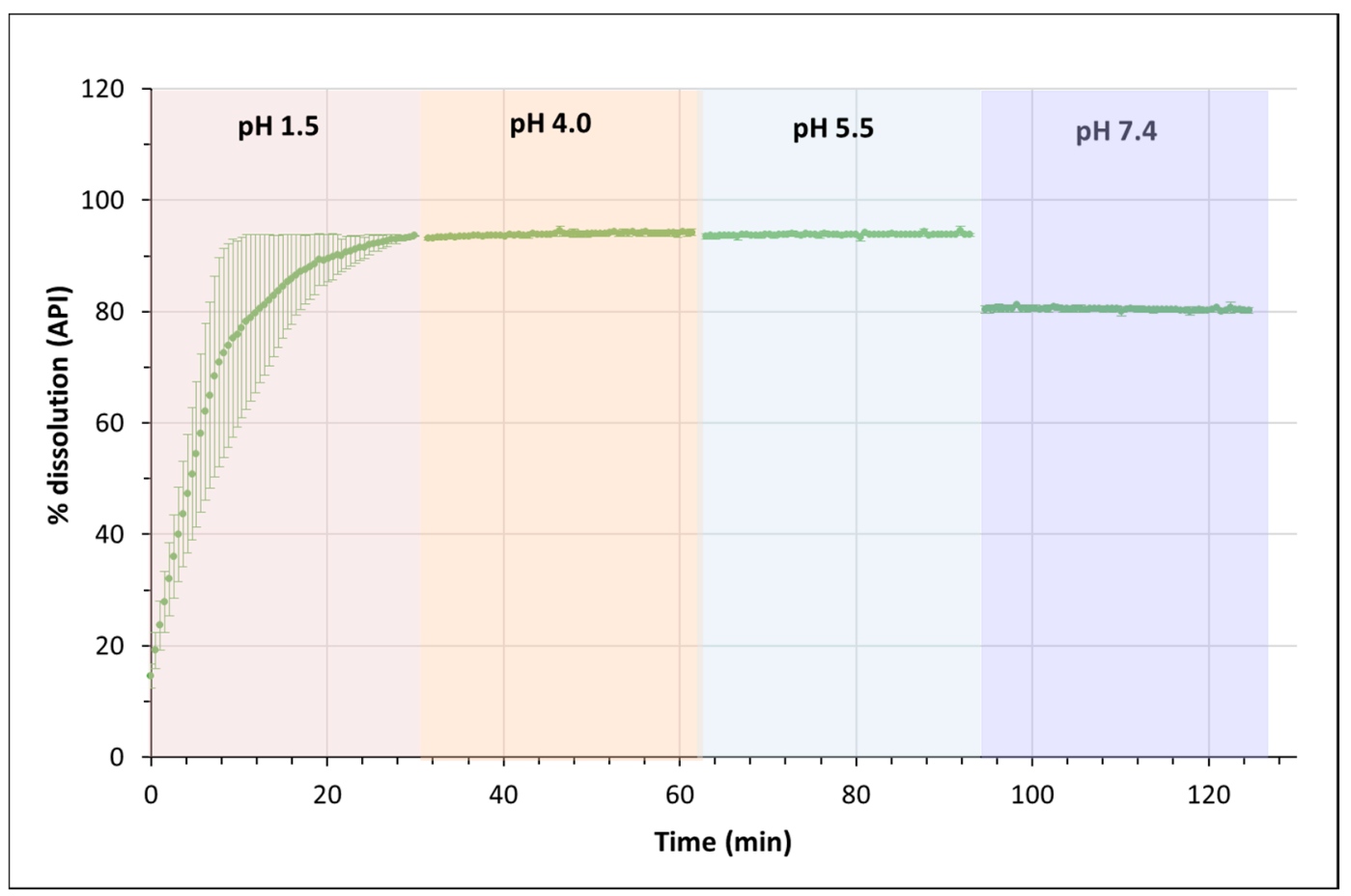

Figure 6. Dissolution profile of the Norfloxacin-resorcinol cocrystal in a 4-sector $\mathrm{pH}$ test.

Here, almost complete dissolution was obtained at $\mathrm{pH} 2.0$, and the dissolved amount was the same at $\mathrm{pH} 4.0$ and 5.5. Notice that, in this test, almost all the API was in the solution already when the $\mathrm{pH}$ changed from 2.0 to 4.0 , so the $\mathrm{pH}_{\mathrm{x}=0}$ effect was not present. As the API is completely positively charged at $\mathrm{pH} 4.0$, the concentration does not change. When pH 5.5 is reached, around $12 \%$ of the compound is already in the zwitterionic form (Figure S12), but the concentration of Norfloxacin in the solution is maintained. When the $\mathrm{pH}$ increases to 7.4 , there is a sudden precipitation caused by the decrease in solubility at 
this $\mathrm{pH}$, although $80 \%$ of the API remains in the solution. It must be pointed out that this kind of test, where the compound is subjected to different $\mathrm{pH}$ values over time, should be more similar to the real processes in the GIT.

XRPD analysis showed again the transformation of both solid forms during the dissolution tests, with the same results already observed in the solubility determinations.

\section{Conclusions}

The crystal form of Norfloxacin, a poorly soluble BCS class IV fluoroquinolone antibiotic, has been modified by cocrystallization with resorcinol. The Norfloxacin-resorcinol cocrystal has been obtained in two different crystal forms, one anhydrous and one monohydrate, with the same (1:1) API/coformer stoichiometry. The anhydrous form can be obtained by solvent-mediated transformation in toluene. The monohydrate is obtained when the anhydrous form is in contact with an aqueous solution.

Although the solubility and dissolution rate determinations have been conducted using the anhydrous form, the final results belong to the hydrated cocrystal since transformation occurs during the course of the determination.

Solubility determination indicates a 10-fold increase in the solubility of the cocrystal compared to the solubility of Norfloxacin itself. The dissolution rate at biorelevant GIT $\mathrm{pH}$ values shows that dissolution is complete for both (API and cocrystal) at $\mathrm{pH} 2.0$, since Norfloxacin is totally protonated at this $\mathrm{pH}$. Although the dissolution rate at $\mathrm{pH} 4.0$ was expected to be similar to the one at $\mathrm{pH} 2.0$, it decreases markedly due to the $\mathrm{pH}_{\mathrm{x}=0}$ effect. However, the presence of a coformer in the cocrystal reduces, to some extent, the buffering effect of Norfloxacin, so that the cocrystal dissolves faster than the pure API. Finally, both solid forms present the lowest dissolution rate at $\mathrm{pH} 7.4$, the $\mathrm{pH}$ at which API has the minimum solubility. When the dissolution rate of the cocrystal was tested in a dynamic manner, in which the $\mathrm{pH}$ changed from 2.0 to 7.4, remaining for $30 \mathrm{~min}$ at each biorelevant $\mathrm{pH}$, the percentage of Norfloxacin in the solution was practically $90 \%$ from $\mathrm{pH} 2.0$ to $\mathrm{pH} 5.5$. Only when the $\mathrm{pH}$ is changed to 7.4 is there a sudden drop in the concentration, although $80 \%$ of the total Norfloxacin remains dissolved, which could potentially contribute to complete absorption throughout the gastrointestinal tract upon oral administration.

Supplementary Materials: The following are available online at https:/ / www.mdpi.com/article/ 10.3390/pharmaceutics14010049/s1, Figure S1: XRPD of Norfloxacin initial batch as received from Sigma-Aldrich, Figure S2: DSC of Norfloxacin-resorcinol cocrystal, Figure S3: TGA of Norfloxacinresorcinol cocrystal, Figure S4: XRPD of Norfloxacin-resorcinol cocrystal, Figure S5: ${ }^{1} \mathrm{H}-\mathrm{NMR}$ of Norfloxacin-resorcinol cocrystal, Figure S6: DSC of Norfloxacin-resorcinol cocrystal monohydrate, Figure S7: DSC (crucible without hole) of Norfloxacin-resorcinol cocrystal monohydrate, Figure S8: TGA of Norfloxacin-resorcinol cocrystal monohydrate, Figure S9: XRPD of Norfloxacin-resorcinol cocrystal monohydrate, Figure S10: ${ }^{1} \mathrm{H}-\mathrm{NMR}$ of Norfloxacin-resorcinol cocrystal monohydrate, Figure S11: Norfloxacin and resorcinol molar extinction coefficients, Figure S12: Norfloxacin species distribution diagram, Figure S13: DSC of Norfloxacin tetrahydrate form, Figure S14: TGA of Norfloxacin tetrahydrate form, Figure S15: XRPD of Norfloxacin tetrahydrate form, Figure S16: Comparative XRPD diffractograms of Norfloxacin tetrahydrate form and simulated from the cif. Table S1. Characteristic 2Theta peaks $\left(^{\circ}\right)$ of the new forms of Norfloxacin.

Author Contributions: Conceptualization, C.R., E.F., and R.P.; Methodology, R.B., R.P., C.R. and E.F.; Formal Analysis, H.F. and R.B.; Investigation, R.P., R.B., H.F., C.R. and E.F.; Resources, R.P., C.R. and E.F.; Data curation, R.B. and C.R.; Writing-Original Draft Preparation, H.F., R.P. and E.F.; Writing-Review and Editing, R.P. and E.F.; Supervision, R.P., C.R. and E.F.; Funding Acquisition, C.R. and E.F. All authors have read and agreed to the published version of the manuscript.

Funding: This research was funded by the project CTQ2017-88179-P financed by MCIN/AEI /10.13039/501100011033/ FEDER “Una manera de hacer Europa”. Research recognition by the Catalan Government (2017 SGR 1074) is acknowledged too. H.F.'s research stay was funded by the Erasmus-Mundus Action-2 program, Avempace II project, from the European Union.

Institutional Review Board Statement: Not applicable. 


\section{Informed Consent Statement: Not applicable.}

Conflicts of Interest: The authors declare no conflict of interest.

\section{References}

1. Shargel, L.; Wu-Pong, S.; Yu, A. Applied Biopharmaceutics E Pharmacokinetics, 6th ed.; McGraw-Hill Education: New York, NY, USA, 2012; p. 413.

2. Merisko-Liversidge, E. Nanocrystals: Resolving pharmaceutical formulation issues associated with poorly water-soluble compounds. In Particles, 1st ed.; Marty, J.J., Ed.; Marcel Dekker: Orlando, FL, USA, 2002.

3. Sareen, S.; Mathew, G.; Joseph, L. Improvement in solubility of poor water-soluble drugs by solid dispersion. Int. J. Pharm. Investig. 2012, 2, 12-17. [CrossRef]

4. Brewster, M.E.; Loftsson, T. Cyclodextrins as pharmaceutical solubilizers. Adv. Drug Deliv. Rev. 2007, 59, 645-666. [CrossRef]

5. Korotkova, E.I.; Kratochvíl, B. Pharmaceutical cocrystals. Procedia Chem. 2014, 10, 473-476. [CrossRef]

6. Jones, W.; Motherwell, W.S.; Trask, A.V. Pharmaceutical cocrystals: An emerging approach to physical property enhancement. MRS Bull. 2006, 31, 875-879. [CrossRef]

7. Karimi-Jafari, M.; Padrela, L.; Walker, G.M.; Croker, D.M. Creating cocrystals: A review of pharmaceutical cocrystal preparation routes and applications. Cryst. Growth Des. 2018, 18, 6370-6387. [CrossRef]

8. Babu, N.J.; Nangia, A. Solubility advantage of amorphous drugs and pharmaceutical cocrystals. Cryst. Growth Des. 2011, 11, 2662-2679. [CrossRef]

9. Salmon, D. Building Co-Crystals with Molecular Sense and Supramolecular Sensibility Highlight. CrystEngComm 2005, 7, 439-448.

10. Bhogala, B.R.; Nangia, A. Ternary and quaternary co-crystals of 1,3-cis, 5-cis-cyclohexanetricarboxylic acid and 4,4'-bipyridines. New J. Chem. 2008, 32, 800-807. [CrossRef]

11. Thakuria, R.; Delori, A.; Jones, W.; Lipert, M.P.; Roy, L.; Rodríguez-Hornedo, N. Pharmaceutical cocrystals and poorly soluble drugs. Int. J. Pharm. 2013, 453, 101-125. [CrossRef] [PubMed]

12. Chiarella, R.A.; Davey, R.J.; Peterson, M.L. Making co-crystals the utility of ternary phase diagrams. Cryst. Growth Des. 2007, 7 , 1223-1226. [CrossRef]

13. Childs, S.L.; Rodríguez-Hornedo, N.; Reddy, L.S.; Jayasankar, A.; Maheshwari, C.; McCausland, L.; Shipplett, R.; Stahly, B.C. Screening strategies based on solubility and solution composition generate pharmaceutically acceptable cocrystals of carbamazepine. CrystEngComm 2008, 10, 856-864. [CrossRef]

14. Delori, A.; Friščić, T.; Jones, W. The role of mechanochemistry and supramolecular design in the development of pharmaceutical materials. CrystEngComm 2012, 14, 2350-2362. [CrossRef]

15. Berry, D.J.; Seaton, C.C.; Clegg, W.; Harrington, R.W.; Coles, S.J.; Horton, P.N.; Hursthouse, M.B.; Storey, R.; Jones, W.; Friscic, T. Applying hot-stage microscopy to co-crystal screening: A study of nicotinamide with seven active pharmaceutical ingredients. Cryst. Growth Des. 2008, 8, 1697-1712. [CrossRef]

16. Breda, S.A.; Jimenez-Kairuz, A.F.; Manzo, R.H.; Olivera, M.E. Solubility behavior and biopharmaceutical classification of novel high-solubility ciprofloxacin and norfloxacin pharmaceutical derivatives. Int. J. Pharm. 2009, 371, 106-113. [CrossRef]

17. Takács-Novák, K.; Noszál, B.; Hermecz, I.; Keresztúri, G.; Podányi, B.; Szasz, G. Protonation equilibria of quinolone antibacterials. J. Pharm. Sci. 1990, 79, 1023-1028. [CrossRef]

18. Ross, D.L.; Riley, C.M. Aqueous solubilities of some variously substituted quinolone antimicrobials. Int. J. Pharm. 1990, 63, 237-250. [CrossRef]

19. De Souza, M.V. New fluoroquinolones: A class of potent antibiotics. Mini-Rev. Med. Chem. 2005, 5, 1009-1017. [CrossRef]

20. Basavoju, S.; Boström, D.; Velaga, S.P. Pharmaceutical cocrystal and salts of norfloxacin. Cryst. Growth Des. 2010, 10, 2948-2953. [CrossRef]

21. Velaga, S.P.; Basavoju, S.; Boström, D. Norfloxacin saccharinate-saccharin dihydrate cocrystal—A new pharmaceutical cocrystal with an organic counter ion. J. Mol. Struct. 2008, 889, 150-153. [CrossRef]

22. Ferreira, P.O.; de Almeida, A.C.; dos Santos, É.C.; Droppa Junior, R.; Ferreira, F.F.; Kogawa, A.C.; Caires, F.J. A norfloxacinnicotinic acid cocrystal: Mechanochemical synthesis, thermal and structural characterization and solubility assays. Thermochim. Acta 2020, 694, 178782. [CrossRef]

23. Burdock, G.A. Encyclopedia of Food and Color Additives; CRC Press: Boca Raton, FL, USA; New York, NY, USA; London, UK; Tokyo, Japan, 1997. Available online: https://www.routledge.com/Encyclopedia-of-Food--Color-Additives/Burdock/p/book/9780 849394164?gclid=EAIaIQobChMI5Iyxo4389AIV9hoGAB3q2gyWEAAYASAAEgLmifD_BwE\# (accessed on 18 November 2021).

24. European Food Safety Authority (EFSA). Scientific opinion on the use of resorcinol as a food additive. EFSA J. 2010, 8, 1411. [CrossRef]

25. Barbas, R.; Font-Bardia, M.; Prohens, R. Polymorphism of sildenafil: A new metastable desolvate. Cryst. Growth Des. 2018, 18, 7618-7627. [CrossRef]

26. Barbas, R.; Kumar, V.; Vallcorba, O.; Prohens, R.; Frontera, A. Sildenafil-resorcinol cocrystal: XRPD structure and DFT calculations. Crystals 2020, 10, 1126. [CrossRef]

27. Bofill, L.; de Sande, D.; Barbas, R.; Prohens, R. A New and Highly Stable Cocrystal of Vitamin D3 for Use in Enhanced Food Supplements. Cryst. Growth Des. 2021, 21, 1418-1423. [CrossRef] 
28. Lee, M.J.; Chun, N.H.; Kim, H.C.; Kim, M.J.; Kim, P.; Cho, M.Y.; Choi, G.J. Agomelatine co-crystals with resorcinol and hydroquinone: Preparation and characterization. Korean J. Chem. Eng. 2018, 35, 984-993. [CrossRef]

29. Sanphui, P.; Goud, N.R.; Khandavilli, U.R.; Nangia, A. Fast dissolving curcumin cocrystals. Cryst. Growth Des. 2011, 11, 4135-4145. [CrossRef]

30. Ràfols, C.; Fael, H.; Fuguet, E.; Outhwaite, B.; Lee, S.; Ruiz, R. Dissolution rates of ciprofloxacin and its cocrystal with resorcinol. ADMET DMPK 2018, 6, 61-70. [CrossRef]

31. Barbas, R.; Prohens, R.; Puigjaner, C. A new polymorph of norfloxacin. J. Therm. Anal. Calorim. 2007, 89, 687-692. [CrossRef]

32. Avdeef, A.; Fuguet, E.; Llinàs, A.; Ràfols, C.; Bosch, E.; Völgyi, G.; Verbić, T.; Boldyreva, E.; Takács-Novák, K. Equilibrium solubility measurement of ionizable drugs-consensus recommendations for improving data quality. ADMET DMPK 2016, 4, 117-178. [CrossRef]

33. Baka, E.; Comer, J.E.A.; Takács-Novák, K. Study of equilibrium solubility measurement by saturation shake-flask method using hydrochlorothiazide as model compound. J. Pharm. Biomed. Anal. 2008, 46, 335-341. [CrossRef] [PubMed]

34. EPA. EPA Product Properties Test Guidelines: OPPTS 830.7840, Water Solubility: Column Elution Method; Shake Flask Method; Environmental Protection Agency: Washington, DC, USA, 1998. Available online: https://nepis.epa.gov (accessed on 18 November 2021).

35. Gravestock, T.; Box, K.; Comer, J.; Frake, E.; Judge, S.; Ruiz, R. The “GI dissolution" method: A low volume, in vitro apparatus for assessing the dissolution/precipitation behaviour of an active pharmaceutical ingredient under biorelevant conditions. Anal. Methods 2011, 3, 560-567. [CrossRef]

36. Boultif, A.; Louër, D. Indexing of powder diffraction patterns for low-symmetry lattices by the successive dichotomy method. J. Appl. Crystallogr. 1991, 24, 987-993. [CrossRef]

37. Ràfols, C. Departament d'Enginyeria Química i Química Analítica, Universitat de Barcelona. Martí i Franquès 1-11, 08028 Barcelona, Spain. $\mathrm{pK}_{\mathrm{a}}$ determination of norfloxacin and resorcinol. 2017; Unpublished work.

38. Cabot, J.M.; Fuguet, E.; Ràfols, C.; Rosés, M. Determination of acidity constants by the capillary electrophoresis internal standard method. IV. Polyprotic compounds. J. Chromatogr. A 2013, 1279, 108-116. [CrossRef] [PubMed]

39. Avdeef, A. Multi-lab intrinsic solubility measurement reproducibility in CheqSol and shake-flask methods. ADMET DMPK 2019, 7, 210-219. [CrossRef]

40. Avdeef, A.; Tsinman, O. Miniaturized rotating disk intrinsic dissolution rate measurement: Effects of buffer capacity in comparisons to traditional Wood's apparatus. Pharm. Res. 2008, 25, 2613-2627. [CrossRef] 